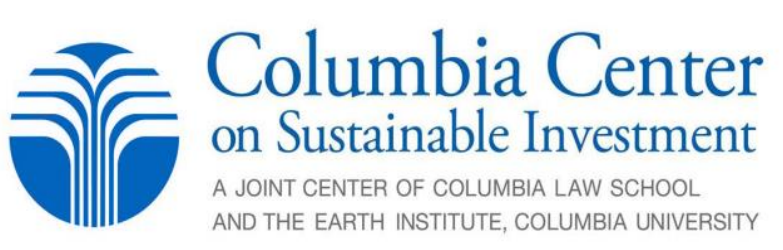

\title{
The Business and Human Rights Arbitration Rule Project: Falling short of its access to justice objectives
}

\author{
Lisa Sachs, Lise Johnson, Kaitlin Cordes, \\ Jesse Coleman, Brooke Guven*
}

September 2019

\section{CCSI Briefing Note}

*Lisa Sachs is the Director of the Columbia Center on Sustainable Investment (CCSI). Lise Johnson is Head of Investment Law and Policy at CCSI. Kaitlin Cordes is Head of Land and Agriculture and leads CCSI's work on Human Rights and Investment. Jesse Coleman and Brooke Guven are Legal Researchers at CCSI. 
Two-thirds of the world's population, 5.1 billion people, lack meaningful access to justice. ${ }^{1}$ According to a recent report, the burden of global injustice reflects and perpetuates existing interand intra-national inequalities, falling most heavily on those who can least afford to bear this burden. While the cost of injustice has 5.1 billion individual faces - people who are not able to, for example, adequately address personal or professional disputes, access public services, or exit situations of extreme injustice and exploitation such as modern slavery - it also includes aggregated costs of reduced GDP and increased global conflict. Access to justice for all is a critical component of global sustainable development, and is embodied in $\underline{\text { SDG } 16}$ and its targets.

In many cases, injustices may be caused or perpetuated by business activity. In 2011, the United Nations Guiding Principles on Business and Human Rights (the "UNGPs") were endorsed by the UN Human Rights Council to articulate the international responsibility of business enterprises to respect human rights, building on states' existing obligations under international law to respect, protect, and fulfill human rights and fundamental freedoms. Appropriate and effective remedies must be provided and accessible when human rights abuses have occurred; these may include recourse to judicial and non-judicial mechanisms.

Yet, injustice persists. It is glaringly clear that many existing dispute settlement mechanisms, individually or in combination, are inadequate, in design or application, to advancing effective remedies, particularly in the context of transnational disputes related to business activity. This is deeply troubling. In response, The Business and Human Rights Arbitration Working Group (the "BHR Arbitration Working Group"), a group of respected practicing lawyers and academics, is advancing international arbitration as a mechanism to help address the remedy gap. With the perspective that "international arbitration holds great promise as a method to be used to resolve human rights disputes involving business," the BHR Arbitration Working Group is working to produce The Hague Rules on Business and Human Rights Arbitration (the "BHR Arbitration Rules"), and has released a draft of those Rules for consultation; final rules are expected by the end of the calendar year.

We are deeply supportive of efforts to increase rights holders' avenues for remedy when they have been harmed. We recognize the need for more mechanisms, including non-judicial mechanisms, to open up access to justice. We admire creative solutions to tough problems, and concrete efforts to advance the "all roads to remedy" approach articulated by the UN Working Group on the issue of human rights and transnational corporations and other business enterprises. ${ }^{2} \mathrm{We}$ are concerned, however, as summarized in an accompanying blog post available here, that the BHR Arbitration Rules Project is not clearly and consistently focused on the access-to-remedy problem it is attempting to solve. Moreover, the Project does not yet adequately address the risk that arbitration may in some cases thwart, rather than advance, access to justice. As a consequence, the Project may ultimately do more harm than good to its aim of increasing access to justice. We urge more work to ensure that arbitration cannot be used to narrow paths to relief, and suggest that additional work with potential claimant rights holders would help in refining the rules so that they are fit for purpose.

\footnotetext{
${ }^{1}$ Task Force on Justice, Justice For All - Final Report (New York, Center on International Cooperation, 2019).

${ }^{2}$ Report of the Working Group on the issue of human rights and transnational corporations and other business enterprises, UN Doc. A/72/162, July 18, 2017.
} 
In this briefing note, we discuss several outstanding issues and suggest ways forward, focusing solely on rights holder-company claims, rather than the business-to-business disputes envisioned as also being handled under the Rules. We begin by articulating a key component of the access to remedy problem - legal rules and systems erected and defended by companies to limit claims and liability - and why and how that element needs to be addressed by the BHR Arbitration Project. We then identify a number of contributions that the BHR Arbitration Project could usefully provide to make arbitration a fair mechanism for advancing claims, and highlight some areas where we see the current Rules as falling short. We conclude with a broader set of recommendations about strategies and processes for improving access to justice for victims of business-related human rights abuses.

\section{Identifying the Problem: Companies don't want to be sued}

The Draft BHR Arbitration Rules state in their Commentary that the rules aim to "provide a means for access to remedy for rights holders affected by business activity." 3 Improving means of access is crucial, as individuals face persistent legal and practical barriers when trying to bring claims against corporations for alleged human rights abuses. In some contexts, domestic legal systems of the country where the harm occurred struggle to provide functioning, well-resourced, and accessible courts. In many cases, there are significant legal and practical hurdles to accessing justice in the home jurisdiction(s) of the corporate entity. However, the challenges victims of human rights abuse face in securing relief in courts can be partly attributed to the barriers that companies themselves have fought for and defended. ${ }^{4}$ These limits include those arising from doctrines of forum non conveniens, legal rules restricting which entities in the corporate group can be sued for what and where, norms shielding parent companies from liability for conduct of their subsidiaries, and legal tools companies can use to move assets across borders and across legal entities to shield them from execution. ${ }^{5}$

\footnotetext{
${ }^{3}$ Commentary at 3 .

${ }^{4}$ In Kiobel v. Royal Dutch Petroleum, for instance, dozens of companies and industry associations filed briefs in support of Shell Petroleum and its fellow corporate respondents, arguing against US courts' jurisdiction over claims regarding human rights violations suffered abroad. The briefs broadly framed the issues being considered, arguing that the US Supreme Court should use the opportunity to hold that US courts categorically lack jurisdiction over Alien Tort Statute (ATS) claims relating to human rights abuses abroad, and also that the ATS does not permit claims against corporations. These amicus briefs, filed on February 3, 2012, and August 8, 2012, are available at https://www.scotusblog.com/case-files/cases/kiobel-v-royal-dutch-petroleum/. See also John Ruggie, "Kiobel and Corporate Social Responsibility," Harvard Kennedy School of Government (September 4, 2012) (raising questions about Shell's arguments and their consistency with the company's human rights responsibilities); Lyle Denniston, “Argument Preview: Will an Old Law Shrink," Scotusblog.com, September 27, 2012, available at https://www.scotusblog.com/2012/09/argument-preview-will-an-old-law-shrink/ (accessed August 20, 2019) (providing an overview of the arguments). See also Daimler AG v. Bauman, and briefs filed in that case by petitioner Daimler AG and other firms and industry associations, available at https://www.scotusblog.com/casefiles/cases/daimlerchrysler-ag-v-bauman/.

${ }^{5}$ These and other barriers are described, e.g., in Gwynne L. Skinner, Beyond Kiobel: Providing Access to Judicial Remedies for Violations of International Human Rights Norms by Transnational Business in a New (Post-Kiobel) World, 46 Colum. Human RighTS. L. REV. 158, 234-36 (2014); Gwynne Skinner, Robert McCorquodale, and Olivier De Schutter, The Third Pillar: Access to Judicial Remedies for Human Rights Violations by Transnational Business (2013), https://static1.squarespace.com/static/583f3fca725e25fcd45aa446/t/58657dfa6a4963597fed598b/1483046398204/Th e-Third-Pillar-FINAL1.pdf (accessed August 20, 2019).
} 
The BHR Arbitration Project may help claimants avoid the impact of some of these limitations in the near term - especially the impacts of weak or corrupt courts - but only if and to the extent that companies agree to having claims brought against them in arbitration. In other words, the BHR Arbitration Project relies on the notion that companies will consent to arbitration notwithstanding their fights against claims in other contexts. ${ }^{6}$ This raises the following question: If multinational corporations are fighting jurisdiction (and liability where jurisdiction lies) in host countries, home countries, and elsewhere for human rights abuses, why would such companies consent to arbitrate those disputes? And if they do, is there reason for skepticism as to what would motivate this agreement when the same company raises forum non conveniens, corporate-form-related objections, or similar arguments erecting jurisdictional barriers elsewhere? What conditions might the agreement to arbitrate contain to nullify or reduce claimants' chances for success or potential remedies? ${ }^{7}$ What aspects of arbitration make it more appealing to defendant companies than dispute resolution in courts, and are those aspects likely to be more or less favorable towards potential claimants?

Perhaps, as the BHR Arbitration Project assumes, companies will in fact consent to arbitrate disputes they would have otherwise fought in other forums on jurisdictional or similar grounds, opening up paths to justice that companies (and legal systems) had otherwise closed. But, it must be recognized that a decision by a company to agree to arbitration will likely be made based on an assessment that consent to defend in that forum (1) has cost or other financial (including reputational and liability-related) benefits that other fora do not, and (2) will be accompanied by efforts by respondent/defendants to limit the choice of forum for claimants or to preclude related claims by other non-party claimants. ${ }^{8}$ Thus, arbitration will be agreed to when it has advantages for the corporate defendant. The flipside is that, for victim claimants, arbitration may pose risks that litigation in other forums does not. Prospective claimants may not be aware of these benefits to companies, and risks to claimants, when they agree to arbitrate.

While the company's openness or commitment to suit in a neutral forum may seem advantageous for potential claimants in search of a place for their claims to be heard and remedies secured, there are aspects, costs, and implications of arbitration that potential victims may not be aware of,

\footnotetext{
${ }^{6}$ The BHR Arbitration Project also suggests that states may compel human rights claims to be pursued using these rules, although it is unclear whether that would be through mandates requiring potential claimants to pursue this path, potential defendants/respondents to consent, or both; and it is similarly unclear how such a mandate would be put in place. See Commentary at 3 ("It is also worth noting that for States, the encouragement, facilitation or even prescription to use business and human rights arbitration would also constitute an additional tool for them to fulfill their responsibilities under UN Guiding Principles on Business and Human Rights Pillars I and III.").

${ }^{7}$ Arbitration agreements can include myriad provisions that can impact the costs of the disputes for plaintiffs, their chances of success, the remedies available, the likelihood of obtaining remedies, and the likelihood of and paths to enforcement. These include provisions waiving (or agreeing to) class claims, as well as provisions on: venue of hearings; the legal seat; the language of the arbitration; who is entitled to bring claims against whom and for what; the applicable law; the scope of discovery; and the powers and duties of the arbitrators.

${ }^{8}$ Regarding why companies prefer arbitration in the US context, see also Stephen Ware, Paying the Price of Process: Judicial Regulation of Consumer Arbitration Agreements, 2001 J. DISP. RESOL. 89, 90-91 (2001) (identifying the following factors: it eliminates juries and is assumed to reduce the threat of large damages awards that may be associated with them; arbitration's relatively more confidential nature lessens the risk of adverse publicity; it simplifies and standardizes procedures; the awards are more final and save companies the costs of appeals; arbitration can limit or eliminate the possibility of class actions; it can deter claims through requiring claimants to pay the fees of arbitrators and arbitral institutions; and it can reduce the amount of discovery plaintiffs can get, reducing time and expense and making it more difficult for claimants to prove their claims).
} 
particularly if they are asked to consent to arbitration prior to a dispute taking place. If claimants are forced to arbitrate to the exclusion of other avenues, the fees that must be paid and the rules employed may make claims infeasible ${ }^{9}$ and recovery particularly unlikely. This risk is heightened if claimants make that election prior to a dispute arising. If, for instance, individual claims are of limited financial value as compared to the cost of arbitration (e.g., claims for back-wages in host countries where salaries are low, but the counsel, experts, and arbitrators required to effectively participate are charging fees based on developed-country market prices ${ }^{10}$ ), then the cases may not be worth the cost of pursuit. ${ }^{11}$

To effectively serve the needs of potential victim claimants as the BHR Arbitration Working Group aims to do, these issues must be identified and addressed head-on. The work must be more direct about the motives, opportunities, and challenges of arbitration, and the implications of the varied procedural forms it can take. Otherwise, the BHR Arbitration Rules risk giving companies a "greenwashing" tool they can use to misleadingly advertise their willingness to be held accountable for harms they cause. Companies may stipulate in agreements such as employment contracts, user agreements for infrastructure or public services, or community-investor agreements

\footnotetext{
${ }^{9}$ E.g., because of costs of even initiating arbitration, which are greater than for courts. This could especially dissuade people from bringing claims for relatively small sums (such as back-wages due for low-paying work, slight but routine overcharges on bills, or reimbursement of rent paid on uninhabitable buildings). These issues could be overcome through class or collective claims, but such claims may be barred through express class action prohibitions in arbitration agreements, or doctrines interpreting silence regarding the permissibility of class actions to mean a bar on such types of claims. See, e.g., DIRECTTV, Inc. v. Imburgia, 136 S.Ct. 463 (2015), (Ginsburg, J., and Sotomayor, J., dissenting); see also David H. Webber, Shareholder Litigation without Class Actions, 57 ARIZ. L.REV. 201 (2015) (discussing implications of legal rules making class actions in securities claims less feasible/attractive).

${ }^{10}$ Indeed, while the Bangladesh Accord set an important precedent in terms of multinational firms' willingness to sign onto legally-binding agreements enforceable through arbitration, critiques have been raised about the costs and complexity of the process. As reported by one of the complainants in two arbitration cases under the Accord:
}

Initial arguments centered on admissibility (whether the cases could be heard), choice of law (which country's law should govern the dispute) and procedural matters such as document production. This turned out to be a very heavy and costly process. As no agreement could be reached on a single arbitrator to hear the cases, under the UNCITRAL Rules they went before a panel of three arbitrators, one chosen by the plaintiffs (the global unions), one chosen by the brands and a chair appointed by the PCA. The global unions were required to deposit $€ 150,000$ with the PCA to cover the fees and travel of the three arbitrators and the administrative costs of the PCA [for the two cases].

Jenny Holdcroft, Feature: Supply Chain Justice through Binding Global Agreements (Industriall, January 15, 2019), available at http://www.industriall-union.org/feature-supply-chain-justice-through-binding-global-agreements (accessed August 20, 2019).

The outcome of one of those two cases is confidential. In the other, the parties settled when the company agreed to pay USD2 million toward remediation of more than 150 factories and to contribute an additional USD300,000 to support the work of the global unions improving pay and conditions for workers in global supply chains. The author concludes, "These outcomes show how important it is for global unions to be able to make binding agreements with MNCs that they can subsequently enforce. But the experience also demonstrated the limitations of using existing mechanisms of international arbitration which are neither designed nor suitable for the settlement of industrial disputes." Id.

${ }^{11}$ AT\&T Mobility LLC v. Concepcion, 131 S. Ct. 1740, 1761 (2011) (Breyer, J., dissenting) ("In California's perfectly rational view, nonclass arbitration over such [small] sums will also sometimes have the effect of depriving claimants of their claims ...."); see also Am. Express Co. v. Italian Colors Rest., 133 S. Ct. 2304 (2013). 
relating to natural resource projects, that any or all disputes between the contracting parties will be resolved pursuant to arbitration under the BHR Arbitration Rules. One could view these types of pronouncements and commitments as important ex ante agreements to be judged but one could also view them more skeptically as arrangements enabling companies to ensure they are only judged in accordance with the rules and in the fora that they have agreed to, and that operate in their favor. In short, while the BHR Arbitration Rules may help companies give the appearance of overcoming their resistance to suit, and the "BHR" label may encourage potential claimants to agree to them, BHR arbitration does not necessarily ameliorate access to justice problems and may in fact, exacerbate them, individually or systemically. ${ }^{12}$ Some relevant issues are discussed further below.

Presenting a Fuller View of the Advantages and Disadvantages of Arbitration, and Options for Rights Holders

State-based ${ }^{13}$ litigation and systems of remedy, unquestionably, have flaws and may not be what the disputing parties need or want. Thus, it is useful to explore complementary mechanisms for relief, including arbitration. Unfortunately, however, arbitration as a dispute settlement mechanism has the potential to privilege the powerful and well-resourced over less well-equipped parties. Scholars have raised various concerns, including that arbitration undermines substantive rights, ${ }^{14}$ and creates relatively unchecked potential for abuse, ${ }^{15}$ and that the risks of harm fall

\footnotetext{
${ }^{12}$ See Gwynne L. Skinner, Beyond Kiobel: Providing Access to Judicial Remedies for Violations of International Human Rights Norms by Transnational Business in a New (Post-Kiobel) World, 46 Colum. Human RigHTS L. ReV. 158, 181 (2014).

${ }^{13}$ As is well known, the state also plays a role in arbitration, e.g., enforcing agreements to arbitrate and enforcing awards. Without such state support, arbitration would be limited in terms of its utility, efficiency, and effectiveness. Thus, arbitration does not mean an absence of the state. (See also Matthew A. Shapiro, Delegating Procedure, 118 COLUM. L. REV. 983 (2018)). But by "state-based" we mean court systems. Diane Desierto suggests our critique of BHR arbitration is based on a view of arbitration as somehow providing "inauthentic" access to justice since it is not provided by the state. But, as reflected in this piece and in our previous comments to the Working Group's work, that is not our concern. See Diane Desierto, "Why Arbitrate Business and Human Rights Disputes? Public Consultation Period Open for the Draft Hague Rules on Business and Human Rights Arbitration" EJIL: Talk! (July 12, 2019) < https://www.ejiltalk.org/public-consultation-period-until-august-25-for-the-draft-hague-rules-onbusiness-and-human-rights-arbitration/>; CCSI, Submission to the Drafting Team of the Hague Rules on Business and Human Rights Arbitration (January 31, 2019) < http://ccsi.columbia.edu/2019/02/21/business-and-humanrights-arbitration/>.

${ }^{14}$ See, e.g., J. Maria Glover, Arbitration, Transparency, and Privatization, Disappearing Claims and the Erosion of Substantive Law, 124 YALE L.J. 3052 (2015);

${ }^{15}$ The abuse can be abuse of power by the other party or parties to the arbitration, or abuse by the arbitrator. In this context, laws governing judicial review of the enforceability of arbitration agreements and awards can help prevent or remedy a number of potentially abusive scenarios, such as enforcement of arbitration agreements that are unconscionable, that require arbitration in places costly and relatively inaccessible to claimants, or that structure procedural rules so as to effectively preclude success. See, e.g, Matthew A. Shapiro, Delegating Procedure, 118 COLUM. L. REV. 983 (2018) (noting ways courts can play a greater role in preventing or addressing abuse in arbitration so as to ensure the state is not complicit in such abuse); Arpan A. Sura and Robert A. DeRise, Conceptualizing Conception: The Continuing Viability of Arbitration Regulations, 62 U. KAN. L. REV. 403 (2013) (outlining how such aspects of arbitration agreements may or may not be regulated by different layers of domestic law (and judicial interpretations thereof)). The abuse may also be due to the conduct of the arbitrator. While awards may be set aside or vacated due to characteristics or conduct of the arbitrator, review of the arbitrators' errors of facts or law is generally limited. Furthermore, and potentially reducing incentives on arbitrators and associated actors to perform their roles diligently, Article 16 of the BHR Arbitration Rules states, "Save for intentional wrongdoing, the parties waive, to the fullest extent permitted under the applicable law, any claim against the
} 
disproportionately on the weaker party. ${ }^{16}$ These critiques do not necessarily mean that arbitration should be avoided for complaints against companies relating to human rights abuses, but they do demonstrate the care that should be taken upfront when advocating a greater role for arbitration and particular Rules for resolving these kinds of disputes. This provides an important opportunity for the BHR Arbitration Project, which could do a number of things to further identify and address such issues, thereby helping to craft a legal system that addresses longstanding remedy gaps.

\section{Developing annotated texts of options}

In addition to the careful development of the arbitration rules themselves, to ensure that the use of the rules levels, rather than further tilts, playing fields, ${ }^{17}$ the BHR Arbitration Project could also help claimants understand the rules (and, as discussed briefly below, the broader systems in which they sit, including domestic arbitration laws and international conventions on enforcement) to make more informed choices when the rules are used. As compared to litigation, arbitration generally contains more gaps that can or must be filled by agreement of the parties or by a decision of the tribunal, such as regards the arbitral seat, approaches to fee-shifting, applicable law, and the rules governing potentially outcome-determinative issues relating to burdens of proof, evidence, disclosure, discovery, and third party participation. From an access to justice perspective, an annotated guide that explains to potential claimants alleging rights violations the various issues to be agreed upon, the associated options available, and the implication of those options (e.g. companies may seek $\mathrm{X}$ in this context, which could have $\mathrm{Y}$ and $\mathrm{Z}$ outcomes) would go some way towards advancing equality of arms. While it might not fully level the playing field, a guide could at least help claimants identify how to use arbitration to enable claims that state-based procedural rules and evidentiary doctrines might otherwise foreclose.

\section{Developing rules with claimants in mind}

Rights holders' access to justice challenges are broad and well-documented, and arise from a diverse set of often-related factors relevant in litigation and arbitration contexts. These include the (1) legal costs associated with pursuing claims (on an absolute basis and relative to the monetary

\footnotetext{
arbitrators, the appointing authority and any person appointed by the arbitral tribunal based on any act or omission in connection with the arbitration." This is taken from the UNCITRAL Arbitration Rules. Although it is important to ensure decisionmakers are not susceptible to undue pressure that might threaten their independence and neutrality, this narrowing of accountability for arbitrators, appointing authorities, and others for any conduct "in connection with the arbitration", is not necessarily an optimal rule for BHR Arbitration.

${ }^{16}$ See, e.g.,; Pat K. Chew, Twenty Years after the 1991 Civil Rights Act: What Does the Future Hold?: Arbitral and Judicial Proceedings: Indistinguishable Justice or Justice Denied, 46 WAKE FOREST L. REV. 185, 204 (2011) (finding that plaintiffs in racial harassment arbitrations seemed to have a lower rate of success than plaintiffs in racial harassment cases brought before courts); J.S. Colvin, An Empirical Study of Employment Arbitration: Case Outcomes and Processes, 8 J. EMPIRICAL LEGAL STUD. 1 (2011) (comparing employee success rates in employment arbitration v employment litigation, and finding lower success rates in arbitration; success also seemed tied to employers' repeat player status, and their re-appointment of the same arbitrator); Richard Delgado et al., Fairness and Formality: Minimizing the Risk of Prejudice in Alternative Dispute Resolution, 1985 WIS. L. REV. 1359,1400 (1985).

${ }^{17}$ See, e.g., See, e.g, Matthew A. Shapiro, Delegating Procedure, 118 CoLUM. L. REV. 983 (2018) (discussing some of the ways that arbitration laws (or interpretations thereof) can be designed to limit the potential for harm or use of arbitration in ways that offends public values); Arpan A. Sura and Robert A. DeRise, Conceptualizing Conception: The Continuing Viability of Arbitration Regulations, 62 U. KAN. L. REV. 403 (2013) (same).
} 
value of the claims), (2) technical expertise needed to pursue cases, (3) substantive and procedural rules making success difficult or impossible, (5) challenges in accessing information necessary to prevail; and (6) risks associated with bringing claims, including potential financial or legal liability. In light of these issues, the Project could have usefully designed rules that specifically help victim claimants overcome those challenges. While companies may resist or try to change provisions they consider favorable to claimants, rules designed in the claimants' interests could at least help support claimants in their engagement with respondent parties who seek to modify or fill gaps in otherwise applicable arbitration rules. Optimal rules for claimants, with explanatory text to illuminate their implications, could reduce the time (and money) spent in individual cases crafting and agreeing on provisions dealing with complex issues, such as the appropriateness of and rules governing mass claims, particularly as victim claimants may struggle to afford highpriced legal counsel experienced in arbitration. ${ }^{18}$

At present, however, the BHR Arbitration Rules are not drafted from a rights holder-claimant's perspective, and indeed leave potential claimants unduly exposed to a system that can undermine their rights. The Rules' default position on costs, for instance, would have unsuccessful (which may include partially successful) claimants bear their and the defendant company's legal costs, a possibility that would likely deter legitimate claims, especially if defendant companies are expected to employ high-priced legal counsel. ${ }^{19}$ The tribunal is given discretion to modify that cost-shifting rule, but there is no ex ante certainty regarding whether and how such discretion would be applied, nor a clear mechanism for effectively challenging those decisions. Additionally, with respect to class actions, the Rules aim to "set aside the presumption that exists in certain jurisdictions whereby an agreement to arbitrate is construed as a waiver of the right to proceed with a class, mass, collective or multi-party action in any forum." But the Rules do not make clear that class claims are allowed, even where they would be in relevant domestic fora. ${ }^{20}$ Rather, they leave to the tribunal's discretion whether such claims will be allowed. A victim-centered set of rules should at least provide claimants the same rights to bring claims as they would have under domestic law, not less.

\footnotetext{
${ }^{18}$ Some may argue that if BHR Arbitration were available, claimants could secure experienced legal support, including support from NGOs focused on impact litigation, to help them with their cases. While this may be true, there are reasons to suspect that it will be harder for resource-strained NGOs to make the case that they should pursue claims in arbitration than through courts, particularly as the "impact" of a successful outcome in arbitration may have less of a systemic value than one in an open court proceeding. On challenges facing rights holders affected by land-based investments in accessing legal and technical support, see CCSI, Addressing Legal Support Gaps Around Land-Based Investment < http://ccsi.columbia.edu/work/projects/addressing-legal-support-gaps-aroundland-based-investment/> accessed August 30, 2019.

${ }^{19}$ See, e.g., Green Tree Financial Corp. v. Randolph, 531 U.S. 79 (2000) (recognizing that a cost-shifting provision in an arbitration agreement could render it unenforceable, but reversing the Court of Appeals determination that silence with respect to costs and fees was unenforceable); see also, Gandee v. LDL Freedom Enters., 293 P.3d 1197, 1200-1201 (Wash. 2013) (finding a "loser-pays" provision to be substantively unconscionable). Other approaches that take account of the impact of fee-shifting statutes, and that aim to address them and improve access to justice for poorer litigants are possible. See, e.g., Issacher Rosen-Zvi, Just Fee Shifting, 37 FLA. ST. U.L. REV. 717 (2010) (arguing for a one-way fee shifting rule under which courts would award attorneys' fees to winners when those winners are poor litigants prevailing against more moneyed opponents, and under which each side would bear its own costs when the rich party prevails).

${ }^{20}$ Commentary to Article 17, p. 24.
} 
Another area where the Rules seem notably unfavorable towards victims is the provision expressly incorporating the doctrine of separability, ${ }^{21}$ which calls on arbitrators to enforce an agreement to arbitrate even where the contract in which that arbitration agreement forms a part would be void or unenforceable. This provision would potentially have tribunals close their eyes to circumstances in which the agreement to arbitrate between a firm and victim claimants was secured through duress, fraud, or misrepresentation by the company, an outcome particularly disconcerting in a context where the would-be claimants are often vulnerable to abuse.

The Rules' provisions on early dismissal of claims lacking legal or factual merit, ${ }^{22}$ which the Commentary notes were inserted so as to respond to the business community's concerns, ${ }^{23}$ also skew the dispute settlement system against rights-holder claimants. The vagueness of such provisions - including the lack of clarity regarding the standards for granting such motions, relevant burdens of production and proof, available discovery, and relevant rules of evidence makes it exceedingly difficult for claimants to know whether this provision will make it more or less likely that their claims will survive in arbitration as compared to litigation. Although the Commentary recognizes and directs the tribunal to anticipate and address some of the ways this rule could disadvantage already disadvantaged claimants, that guidance is not clearly reflected in the Rules themselves, and will have uncertain effect in shaping actual tribunal decisions. ${ }^{24}$

A further issue relates to the Rules' provisions on counterclaims, orders of interim relief, and penalties for non-compliance with orders for interim measures. ${ }^{25}$ While the reasoning behind permitting such actions is rational, if such provisions are not accompanied by appropriate protections, they could be improperly used to intimidate plaintiffs into dropping their claims, and to pressure or order plaintiffs to halt other actions such as protests, strikes, or publicity campaigns. ${ }^{26}$ A frivolous counterclaim by a defendant company, for example, might be designed to intimidate rights holder claimants. To avoid such scenarios, the BHR Arbitration Rules could take guidance from "anti-SLAPP" rules that seek to limit the use of domestic litigation for abusive and retaliatory purposes and to protect the rights of public protest and lawsuits against enterprises or other powerful parties. ${ }^{27}$ Currently, the BHR Arbitration Rules, including the tribunal's broad power to order sanctions for non-compliance with orders of interim measures, may exacerbate the

\footnotetext{
${ }^{21}$ Article 23(1).

${ }^{22}$ Article 23-bis.

${ }^{23}$ Commentary to Article 23-bis.

${ }^{24}$ Commentary to Article 23-bis.

25 Article 21(3)(counterclaims); Article 26 (interim measures).

${ }^{26}$ Article 26(1) states that an "arbitral tribunal may, at the request of a party, stipulate any monetary penalty it deems appropriate for non-compliance with its interim measures"

27 The term "SLAPP" suits refers to a "Strategic Lawsuit Against Public Participation," which may be generally defined as actions brought by businesses or other powerful actors to stifle the exercise of free speech and prevent plaintiffs from petitioning the government for redress. SLAPP suits are one means used by companies to combat claims against them relating to human rights abuses and other harms. To prevent and/or remedy the effects of SLAPP suits, some jurisdictions have adopted anti-SLAPP laws. See, e.g., Cal. Civ. Proc. Code $\$ 425.16$; NY Civil Rights Law $\$ \$ 70-\mathrm{a}$, See also Tyler J. Kimberly, Note, A SLAPP Back on Track: How Shady Grove Prevents the Application of Anti-SLAPP Laws in Federal Courts, 65 Case W. Res. L. Rev. 1201 (2015) (discussing how state anti-SLAPP laws differ from federal procedural rules regarding dismissal of meritless claims). For relevance in human rights context, see also Gwynne L. Skinner, Beyond Kiobel: Providing Access to Judicial Remedies for Violations of International Human Rights Norms by Transnational Business in a New (Post-Kiobel) World, 46 COLum. Human Rights. L. REV. 158, 234-36 (2014).
} 
chilling effects of retaliatory company actions; they could be amended, however, to include rules or mechanisms that deter and/or penalize such actions. ${ }^{28}$

More broadly, while there are provisions in the Rules that aim to combat asymmetries in legal knowledge, resources, and power, they are vague and of potentially limited effect. Article 5(2), in particular, provides three criteria that must be satisfied before a tribunal is called upon to take affirmative action to ensure fairness, and even then the tribunal's duty is to "endeavor" to ensure fairness, not to actually ensure it. ${ }^{29}$

Similarly, there is little in the Rules to help ensure that arbitrations will not be cost prohibitive to pursue. Commentary to the Rules states that "the arbitral tribunal should pay particular attention to how to enhance access and reduce costs through the use of multiple languages, translation and interpretation, while at the same time resorting to such tools only where needed in order not to increase costs unduly." ${ }^{30}$ But the Rules themselves do not provide that instruction; and there are no similar dictates in the Rules governing other issues that can similarly have significant cost and access implications, such as the location of hearings. Without more, it is uncertain whether tribunals will feel empowered or inclined to take appropriate proactive measures to adequately remedy power asymmetries between disputing parties. ${ }^{31}$

\section{Addressing arbitration's legal infrastructure - contracts, laws, and conventions}

Additionally, the Project could examine whether and to what extent provisions in arbitration agreements, model and actual laws on arbitration, and conventions on enforcement are appropriate for the BHR context, and explore whether and what changes to those arbitration-related instruments would help close remedy gaps and prevent abuses. Regarding the contents of arbitration agreements, the Project could further elaborate on options for and implications of different "applicable law" clauses governing both substantive matters of rights and obligations, as well as the law governing interpretation of the contract and arbitration agreement. Relatedly, the

\footnotetext{
${ }^{28}$ Although the Rules contain a provision regarding dismissal of meritless claims (including counterclaims), these are not necessarily the same as anti-SLAPP actions. The latter are sometimes accompanied by timelines, burdens of proof, and specific penalties, that are not applicable to other preliminary motions to dismiss. Even where antiSLAPP laws are in force domestically, it is not clear that they will protect victim claimants' arbitration claims from counterclaims pursued in arbitration. See, e.g., Sheppad v. Lightpost Museum Fund, 146 Cal. App. 4th 315 (2006) (holding that California's anti-SLAPP statute does not apply to alleged SLAPP claims pursued in arbitration); but see Pat Murphy, Anti-SLAPP Protection Applies to FINRA Arbitration, Mass. Lawyers Weekly, July 10, 2018 (holding that the state's anti-SLAPP statute applied to protect a Financial Industry Regulatory Authority (FINRA) arbitration, given the relationship between FINRA and the government).

29 "Where a party is unrepresented and has limited financial resources and legal knowledge, the arbitral tribunal shall endeavor, without compromising its independence and impartiality, to ensure that the unrepresented party is given an effective opportunity to present its case in fair and efficient proceedings." Article 5(2). In addition, any "special treatment" of less well-resourced or equipped litigants may also run afoul of Article 17.

${ }^{30}$ Commentary to Article 19, p. 27.

${ }^{31} \mathrm{Cf}$ Report of the Working Group on the issue of human rights and transnational corporations and other business enterprises, UN Doc. A/72/162, July 18, 2017, para. 23 ("II]f there is a power imbalance between the affected rights holders and a given enterprise facing allegations of human rights abuses, persons administering a remedial mechanism should take proactive measures to redress this asymmetrical relationship."); Judith Resnik, The Supreme Court 2010 Term: Fairness in Numbers: A Comment on AT\&T v. Concepcion, Wal-Mart v. Dukes, and Turner v. Rogers, 125 HARV. L. REV. 78 (2011) (discussing ways and struggles of courts to ease asymmetries of power and advance equal treatment before the law).
} 
Project could also help broaden and deepen understanding of whether, when, and how courts should and could be given a greater role in policing the conduct or outcomes of these arbitrations. ${ }^{32}$ Domestic legal systems may be comfortable with limited judicial oversight of arbitration when the disputes being arbitrated are between two sophisticated businesses that are familiar with arbitration; but it is less clear that the same approach is appropriate for all BHR arbitration disputes. Relevant arbitration laws may need appropriate adjustments. A project cataloging such access-tojustice barriers in arbitration agreements and arbitration laws, and helping victims and advocates overcome those barriers, would be an important contribution to efforts to help ensure arbitration improves, and does not undermine, access to justice for rights holders.

\section{Concluding Thoughts and Ways Forward}

At present, the Rules are described as providing "the possibility of a remedy for those affected by the human rights impacts of business activities, ... serving as a non-State-based non-judicial grievance mechanism under Principle 31 of the UN Guiding Principles." 33 But the Project, in ignoring the ways in which companies have used legal tools to fight claims and thus impede access to remedy, has failed to adequately consider how the Rules might be used to further facilitate companies' efforts to undermine access to justice, and how the Rules should thus be drafted to avoid such a situation. Arbitration is a system of high-party autonomy and delegated state power which can create risks for weaker parties, such as rights-holder claimants, yet the Rules pay inadequate attention to mechanisms for avoiding or correcting the abuses that can arise when entities are on vastly unequal footing. The limited and general guidance the Rules give tribunals to address inequalities of arms provides little assurance that tribunals will be willing and able to remedy either systemic or case-specific inequalities.

These issues are part of the set of concerns we had identified in our previous submission to the Working Group based on the Elements Paper, ${ }^{34}$ and about which we remain concerned after having reviewed the Draft Rules.

We reiterate our view that the objective of the Project - to identify and advance alternative remedies for victims of business-related rights abuses - is timely and critically important. But to serve potential rights-holder claimants, the perils of arbitration (and of the legal infrastructure that surrounds it) for rights holders should be recognized and addressed.

As noted above, some of the major barriers to justice are barriers that companies have constructed and defended through lobbying and litigation. We thus reiterate that any efforts to encourage companies to ease these barriers by submitting to BHR Arbitration also be devoted to influencing corporations to stop undermining access to justice in domestic courts, including securing commitments from companies to:

- waive forum non conveniens objections for certain types of human-rights related claims;

\footnotetext{
${ }^{32}$ For some suggestions of greater involvement by courts in arbitration, see Shapiro, supra.

${ }^{33}$ BHR Arbitration Rules, Preamble.

${ }^{34}$ CCSI, Submission to the Drafting Team of the Hague Rules on Business and Human Rights Arbitration (January 31, 2019) < http://ccsi.columbia.edu/2019/02/21/business-and-human-rights-arbitration/>.
} 
- agree to produce documents pertaining to the issue of parent company control relevant for establishing responsibility of the parent company for acts of its subsidiaries;

- require their subsidiaries to waive jurisdictional objections to claims brought in the parent's home country;

- commit not to [re]structure for the purpose of judgment-proofing their assets;

- commit not to engage in anti-SLAPP suits; and

- agree to adhere to specified standards of responsible conduct in their business activities.

Finally, we urge that the Project further open its process to pull in insights from rights holders, especially those currently plagued by access to justice challenges. While the Elements Paper and Draft Rules were open for public comment, we urge a more concerted effort to seek out, secure, and engage with input specifically from rights holders and their advocates. As the UN Working Group on Business and Human Rights has reiterated, "human rights are best advanced when the 'experiences, perspectives, interests, and opinions [of the rights holders] deeply inform how remedy mechanisms are created and implemented'." 35 The Working Group has further explained that rights holders "should be consulted meaningfully in creating, designing, reforming and operating such mechanisms. Such engagement would ensure that remedial mechanisms and their processes are geared towards protecting and redressing the rights of communities affected by business-related human rights abuses." 36 While the BHR Arbitration Project has undertaken useful efforts to engage with a range of stakeholders, meaningful consultation of rights holders is not evident. An additional proactive effort to actively seek out and incorporate the perspectives of rights holders-including, for example, representatives of communities that have suffered adverse business impacts in the past, and that have attempted to seek remedy, as well as workers and indigenous peoples - and to audit each of the Rules from their perspective and based on their needs, would make it more likely that the Project does indeed result in a new mechanism that improves access to remedy for rights holders affected by business activity.

\footnotetext{
${ }^{35}$ Report of the Working Group on the issue of human rights and transnational corporations and other business enterprises, UN Doc. A/72/162, July 18, 2017, para. 21, quoting Columbia Law School Human Rights Clinic and Harvard Law School International Human Rights Clinic, "Righting wrongs? Barrick Gold's remedy mechanism for sexual violence in Papua New Guinea - key concerns and lessons learned" (2015), p. 44.

${ }^{36}$ Report of the Working Group on the issue of human rights and transnational corporations and other business enterprises, UN Doc. A/72/162, July 18, 2017, at para. 22.
} 